\title{
Codon usage in the Mycobacterium tuberculosis complex
}

\author{
Siv G. E. Andersson ${ }^{1}$ and Paul M. Sharp ${ }^{2}$ \\ Author for correspondence: Paul M. Sharp. Tel: +44 115970 9263. Fax: +44 1159709906. \\ e-ma1l: pdzpms@evol.nott.ac.uk
}

1 Department of Molecular Biology, Biomedical Center, Uppsala University, Uppsala, S-75124, Sweden

2 Department of Genetics, University of Nottingham, Queen's Medical Centre, Nottingham NG7 2UH, UK

\begin{abstract}
The usage of alternative synonymous codons in Mycobacterium tuberculosis (and $M$. bovis) genes has been investigated. This species is a member of the high-G + C Gram-positive bacteria, with a genomic $\mathbf{G}+\mathbf{C}$ content around $65 \mathrm{~mol} \%$. This $\mathrm{G}+\mathrm{C}$-richness is reflected in a strong bias towards C- and Gending codons for every amino acid: overall, the $G+C$ content at the third positions of codons is $\mathbf{8 3} \%$. However, there is significant variation in codon usage patterns among genes, which appears to be associated with gene expression level. From the variation among genes, putative optimal codons were identified for 15 amino acids. The degree of bias towards optimal codons in an $\boldsymbol{M}$. tuberculosis gene is correlated with that in homologues from Escherichia coli and Bacillus subtilis. The set of selectively favoured codons seems to be quite highly conserved between $M$. tuberculosis and another highG+C Gram-positive bacterium, Corynebacterium glutamicum, even though the genome and overall codon usage of the latter are much less $\mathbf{G}+\mathbf{C}$-rich.
\end{abstract}

Keywords: codon usage, Mycobacterium tuberculosis, molecular evolution, intein

\section{INTRODUCTION}

Analyses of patterns of synonymous codon usage can reveal fundamental features of molecular evolution, and provide information of practical application in molecular biology. Codon usage is influenced by mutational biases, upon which the effects of natural selection may be superimposed (for a review, see Sharp et al., 1993). Codon usage patterns are best understood in the Gram-negative bacterium Escherichia coli, where it seems clear that certain codons - those best recognized by the most abundant tRNA species - are translationally optimal (Ikemura, 1981). These optimal codons are strongly 'preferred' in highly expressed genes, whereas in genes expressed at low levels codon usage is more uniform (Ikemura, 1981; Gouy \& Gautier, 1982). Codon usage in the low-G + C Gram-positive species Bacillus subtilis is similar to that in E. coli insofar as there are certain optimal codons which are more strongly preferred in more highly expressed genes, but differs in two respects: for some amino acids the optimal codons are different from those in E. coli, presumably reflecting differences in the tRNA populations of the two species, and overall the strength of codon usage bias is weaker (Shields \& Sharp, 1987; Sharp et al., 1990).

Abbreviations: $C A$, correspondence analysis; $C A$, codon adaptation index; $F_{\text {op }}$ frequency of optimal codons; $N_{\mathrm{c}}$, effective number of codons; RSCU, relative synonymous codon usage.
In contrast, in some bacterial species there appears to be little difference between the codon usage profiles of genes expressed at high and low levels, and so little evidence that translational selection has been effective. Several such species have extreme genomic base composition, being either very A+T-rich, e.g. Mycoplasma capricolum (Ohkubo et al., 1987), or very G + C-rich, e.g. Micrococcus luteus (Ohama et al., 1990) and Streptomyces species (Wright \& Bibb, 1992). In these cases, the mutational biases seem to swamp any selection for particular codons, although it is also possible that tRNA profiles have adapted so that many of the codons favoured by the mutational bias have become optimal (Shields, 1990). Differences in the strength and efficacy of selection for optimal codons could also result from differences in the ecological/population genetics of various species.

As yet, rather few other bacterial species have been examined in any detail with respect to their codon usage. To gain any insight, it is essential that sequences should be available for genes expressed at different levels, and it is usually necessary to subject the data to multivariate statistical analyses to characterize any heterogeneity among genes. Thus, while codon usage compilations have been made for a number of other species (e.g. Wada et al., 1992), the variation among genes has not been examined. Here we investigate codon usage in Mycobacterium tuberculosis. The molecular biology of this species is of great interest, since it is a human pathogen. It is the causative 
agent of tuberculosis, responsible for around 3 million deaths per year; among infectious diseases it is the leading cause of death in man (Bloom \& Murray, 1992). There are two reasons why codon usage in $M$. tuberculosis may not show evidence of translationally selected bias. First, like Micrococcus and Streptomyces, it is a member of the high$\mathrm{G}+\mathrm{C}$ Gram-positive bacteria (Olsen et al., 1994), although its genomic $\mathrm{G}+\mathrm{C}$ content is rather lower than in these other species (about $65 \mathrm{~mol} \%$, compared to about $75 \mathrm{~mol} \%$ ). Second, M. tuberculosis multiplies almost exclusively in macrophages, with a doubling time of about $24 \mathrm{~h}$ : if codon selection were mediated by the need for efficient use of ribosomes during periods of rapid growth (Andersson \& Kurland, 1990), such selection may not be effective in this species. Thus, it is particularly interesting to ask whether genes expressed at high and low levels in $M$. tuberculosis differ in their codon usage.

\section{METHODS}

Sequences. DNA sequences were taken from the GenBank/ EMBL/DDBJ DNA sequence database (GenBank release 87). Database entries identified in their features tables as $M y c o-$ bacterium tuberculosis and $M$. bovis protein-coding sequences were extracted using the ACNUC retrieval system (Gouy et al., 1985). Searches of the database for homologous sequences were performed using the BLAST program (Altschul et al., 1990). Sequence alignments were performed using CLUSTAL w (Thompson et al., 1994).

For nomenclature, we have tried to follow that in a recent listing of Mycobacterium sequences (Bergh \& Cole, 1994). In the case of antigen sequences, we have followed Young et al. (1992). For the sequences homologous to the groE operon, we have adopted the terminology of Coates et al. (1993).

Analyses. Codon usage in the Mycobacterium sequences was calculated using the program coDons (Lloyd \& Sharp, 1992). As well as numbers of each codon, relative synonymous codon usage (RSCU) values were calculated. The RSCU is the observed frequency of a codon divided by the frequency expected if all synonyms for that amino acid were used equally, and so RSCU values close to 1.0 indicate a lack of bias. RSCU values are useful in comparing codon usage among genes, or sets of genes, encoding proteins with different amino acid compositions.

A number of indices of codon usage bias were calculated for each gene, also using codons, as follows.

$\mathrm{GC}_{\mathrm{s}}$ : the frequency of use of $\mathrm{G}+\mathrm{C}$ in synonymously variable third positions of codons (i.e. excluding Met, Trp and termination codons). In addition, $\mathrm{G}+\mathrm{C}$ values were calculated for each of the three codon positions, ignoring the distinction between silent and replacement sites.

$N_{c}$ : the 'effective number of codons' used in a gene (Wright, $1990)$. This is a general measure of bias away from equal usage of alternative synonyms. Values of $N_{c}$ can range between 20 (in an extremely biased gene, where only one codon is used per amino acid) and 61 (where all synonyms are used with equal probability). However, as $\mathrm{G}+\mathrm{C}$ content at silent sites increases above $50 \%$, the expected value for $N_{\mathrm{c}}$ under random codon usage (that is, random except for the influence of $\mathrm{G}+\mathrm{C}$ content) decreases. The expected value is approximately given by:

$N_{\mathrm{c}}=2+s+\left\{29 /\left[s^{2}+(1-s)^{2}\right]\right\}$

where $s$ is $\mathrm{GC}_{\mathrm{s}}$. See Wright (1990) for details of these calculations. (The expression for the expected value of $N_{\mathrm{c}}$ was misprinted there; F. Wright, personal communication.)
$F_{\text {op }}$ : the 'frequency of optimal codons' used in a gene (Ikemura, 1981). This is a species-specific measure of bias towards those particular codons which appear to be translationally optimal in the particular species. Optimal codons for $M$. tuberculosis were identified (see below) for 15 of the 18 amino acids where alternative synonyms exist. Two optimal codons were identified for Leu and Arg, and one for each of 13 other amino acids. The $F_{\text {op }}$ is calculated as the number of occurrences of these 17 optimal codons, divided by the total number of occurrences of these 15 amino acids.

The major trends in codon usage among genes were investigated using correspondence analysis (Greenacre, 1984). This is the most commonly used multivariate statistical approach in codon usage analysis (see, for example, Grantham et al., 1981; Holm, 1986; Medigue et al., 1991). In essence, this method plots genes according to their synonymous codon usage in a 59-dimensional space, and then identifies the major trends as those axes through this multidimensional hyperspace which account for the largest fractions of variation among genes.

\section{RESULTS}

\section{Selection of DNA sequences for analysis}

Sequences from both Mycobacterium tuberculosis and Mycobacterium bovis were included in the analysis. These two species, along with Mycobacterium microti and Mycobacterium africanum, form the ' $M$. tuberculosis complex', and are so closely related that it has been suggested that they are in fact a single species (reviewed by Grange $e t$ al., 1983). This close relationship is borne out by comparison of homologous genes from $M$. tuberculosis and M. bovis, where very little sequence variation is seen: the chaperonin-60-2 (65 kDa antigen; antigen 2) gene (Shinnick, 1987; Thole et al., 1987), the $19 \mathrm{kDa}$ antigen (antigen 13) gene (Young et al., 1988; Collins et al., 1990), and the $r p s L$ and partial $r p s G$ genes (F. Silbaq \& H. Bercovier, GenBank accession no. L25882; Nair $t$ t al., 1993) are all identical in the two 'species'. Furthermore, the only differences in the $c p n 10$ (also known as groES, encoding chaperonin-10, the $10 \mathrm{kDa}$ antigen; antigen 5) gene sequences (Yamaguchi et al., 1988; Baird et al., 1989) occur near the termination codon, and are such that the reading frame is changed in a region where the $M$. tuberculosis protein is identical to that from Mycobacterium leprae; since $M$. leprae is quite distantly related to $M$. tuberculosis, these differences most likely reflect errors in the $M$. bovis sequence. There are no $M$. africanum proteincoding sequences in the database, and the only one from M. microti, $408 \mathrm{bp}$ within the $32 \mathrm{kDa}$ antigen gene, is also identical to $M$. tuberculosis and $M$. bovis (H. Soini et al., GenBank accession nos. Z33653-Z33656). In contrast, for example, homologous gene sequences from different natural isolates of $E$. coli differ at $1-2 \%$ of nucleotides (see, for example, Hall \& Sharp, 1992).

Duplicate sequences were excluded from the analysis. A number of M. tuberculosis catalase-peroxidase gene (kat $G$ ) sequences occur in the database; we have analysed a consensus sequence. In addition, a number of other sequences identified in the GenBank/EMBL DNA sequence database as potential coding sequences were excluded. The identification of accurate gene sequences in 
M. tuberculosis is difficult because of its high- $\mathrm{G}+\mathrm{C}$ content. First, this can lead to sequencing errors because of compressions in $\mathrm{G}+\mathrm{C}$-rich regions. Second, stop codons, which are $\mathrm{A}+\mathrm{T}$-rich, occur relatively rarely even in noncoding sequences, so that long open reading frames (ORFs) can occur by chance. Third, the first results of the $M$. leprae genome project (Honore et al., 1993) have suggested a surprisingly low gene density in that species (only about $40 \%$ of $36.7 \mathrm{~kb}$ was clearly genic), even though its genome is not unusually large (about $2.8 \mathrm{Mb}$ ); this compares with $88 \%$ coding density in the $4.7 \mathrm{Mb}$ genome of E. coli (Plunkett et al., 1993). One line of evidence that an ORF is indeed a functional gene comes from conservation of the sequence, without frameshifts, and with an excess of changes at silent sites, in other species. In the case of $M$. tuberculosis, a number of sequences can be compared to homologous segments of the $M$. leprae genome, particularly as a result of the $M$. leprae genome project, from which 20 cosmids totalling approximately $770 \mathrm{~kb}$ have been deposited in the database (Honore et al., 1993; D. R. Smith, GenBank accession nos L01095, L01263, L01536, L04666; D. R. Smith \& K. Robison, GenBank accession nos U00010-U00023; H. Fsihi \& S. T. Cole, GenBank accession no. Z46257). A large number of potential coding sequences were excluded because their putative products exhibited no homology to any known protein, because in an alignment with homologous sequences there were insertion/deletion events leading to frameshifts, because they were in substantial overlap with other ORFs more likely to be genes, or because their positional base composition statistics were anomalous (see below). A few specific examples are given below.

A 1434 bp sequence (O'Connor et al., 1990) contains a $812 \mathrm{bp}$ ORF encoding a $35 \mathrm{kDa}$ antigen (antigen 9; Young et al., 1992), but also a $816 \mathrm{bp}$ ORF on the complementary strand. The two ORFs overlap by $684 \mathrm{bp}$ and are in the same phase, i.e. the first codon positions of one are complementary to the third positions of the other. Such complementary ORFs are not uncommon, but are probably a simple consequence of the relative scarcity in real genes of the codons (UUA, UCA and CUA) complementary to stop codons (Sharp, 1985; Merino et al., 1994). In comparison with a homologous sequence from M. leprae (cosmid B2235; D. R. Smith \& K. Robison, GenBank accession no. U00019), most changes in the $812 \mathrm{bp} \mathrm{ORF}$ were silent, whereas most in the $816 \mathrm{bp}$ ORF were not. The 816 bp ORF was excluded.

A $3 \mathrm{~kb}$ sequence (Leao et al., 1995) contains a $1539 \mathrm{bp}$ ORF encoding a phospholipase $\mathrm{C}$ homologue. A second smaller ORF, on the complementary strand, is annotated in the database as encoding the MTP40 protein, but lies completely within the large ORF. The two ORFs are in different phases, sharing third codon positions. Consequently both are $\mathrm{G}+\mathrm{C}$-rich at third positions, but the second codon positions of the MTP40 ORF are more $\mathrm{G}+\mathrm{C}$-rich $(59 \%)$ than the first positions $(53 \%)$, which is most unusual in $M$. tuberculosis genes (see below). Furthermore, within this region the phospholipase $\mathrm{C}$ protein has similarity with phospholipases from Pseudomonas aeruginosa, while the MTP40 ORF is not conserved. The MTP40 ORF was excluded.

Database entries for putative genes encoding dihydrofolate reductase (A. H. Patki \& J. W. Dale, GenBank accession no. X59271) and thymidylate synthase (A. H. Patki \& J. W. Dale, GenBank accession no. X59273) each potentially encode products that showed no detectable homology (in BLAST searches) with dihydrofolate reductase and thymidylate synthase sequences from other species. Furthermore, the thymidylate synthase ORF is not conserved in a homologous region from $M$. leprae cosmid B2235, while the dihydrofolate reductase ORF has a third position $\mathrm{G}+\mathrm{C}$ content of $60 \%, 16 \%$ lower than any of 34 genes analysed below, and $5 \%$ lower than at first positions in this ORF, which is also quite unusual (see below); both ORFs were excluded.

The M. tuberculosis dnaJ gene sequence (R. Lathigra et al., GenBank accession no. X58406) is 33 codons shorter than that of $M$. leprae. This appears to be due to a frameshift near the 3 ' end: insertion of an additional $G$ into a run of three $G$ s at codons 341-342 restores a reading frame with a termination codon at a homologous position to that of $M$. leprae and encoding an amino acid sequence well conserved between $M$. leprae and Streptomyces coelicolor. Sequence after codon 341 was excluded from this analysis.

By comparison with the asd sequence from Mycobacterium smegmatis (Cirillo et al., 1994b), the M. bovis asd gene (Cirillo et al., 1994b) appears to contain a frameshift, due to the deletion of two nucleotides in codons 312-313. Insertion of two nucleotides restores a reading frame in which $14 / 15$ differences between $M$. bovis and $M$. smegmatis are silent; codons 312 and 313 of asd were excluded from the analysis.

By comparison with homologous sequences from $E$. coli and $B$. subtilis, the $M$. bovis rpsK sequence (E. Dubnau et al., GenBank accession no. U15140) may contain as many as four frameshifts, and so was excluded. In the same database entry, there is an ORF ('ORFX') located between $r p m J$ and $r p s M$, and annotated as encoding a ribosomal protein. The putative product has no similarity to any database entry, and furthermore, there is no such ORF between $r p m J$ and $r p s M$ in other bacteria (B. subtilis, Lactococcus lactis, Chlamydia trachomatis and E. coli). ORFX overlaps $r p s M$ by $58 \mathrm{bp}$ and has a base composition quite unlike any other $M$. tuberculosis gene (see below): the $\mathrm{G}+\mathrm{C}$ content at synonymously variable third positions is only $64 \%$, and second positions of codons are far more $\mathrm{G}+\mathrm{C}$-rich $(72 \%)$ than first positions $(45 \%)$. ORFX was excluded from our analysis.

The database contains the sequence of one $M$. tuberculosis cosmid sequence with 23 annotated ORFs (D. R. Smith \& K. Robison, GenBank accession no. U00024). Since these putative genes were not characterized by a directed approach, and most do not have clear homologues in the database, these ORFs were excluded from our analysis.

Several problematic sequences putatively encode antigens. Consequently, we excluded from the analysis all sequences thought to encode antigens, unless these were 
Table 1. M. tuberculosis gene sequences

\begin{tabular}{|c|c|c|c|c|c|c|c|c|}
\hline Gene & Product & AA & GC & $\mathrm{GC}_{\mathrm{s}}$ & $N_{\mathrm{c}}$ & $F_{\mathrm{op}}$ & $\begin{array}{l}\text { Accession } \\
\text { no. }\end{array}$ & Reference $\nmid$ \\
\hline$r p l L^{*}$ & Ribosomal protein L7/L12 & 130 & $0 \cdot 68$ & 0.92 & $25 \cdot 1$ & $0 \cdot 84$ & D16310 & 1 \\
\hline $\operatorname{cpn} 10-1$ & Chaperonin-10-1 (Ag 5; GroES) & 100 & $0 \cdot 64$ & $0 \cdot 88$ & $33 \cdot 5$ & $0 \cdot 70$ & M25258 & 2 \\
\hline$r p s L$ & Ribosomal protein $\mathrm{S} 12$ & 124 & $0 \cdot 63$ & $0 \cdot 81$ & $38 \cdot 0$ & 0.65 & L08011 & 3 \\
\hline $\inf A^{*}$ & Initiation factor 1 & 73 & $0 \cdot 63$ & $0 \cdot 89$ & $34 \cdot 5$ & $0 \cdot 68$ & U15140 & 4 \\
\hline $\operatorname{cpn} 60-2$ & Chaperonin-60-2 (Ag 2; GroEL) & 540 & $0 \cdot 65$ & $0 \cdot 87$ & $31 \cdot 5$ & $0 \cdot 73$ & M15467 & 5 \\
\hline rpss* & Ribosomal protein S19 & 93 & $0 \cdot 58$ & $0 \cdot 81$ & $39 \cdot 1$ & $0 \cdot 61$ & S65565 & 6 \\
\hline tuf & Elongation factor $\mathrm{TU}$ & 396 & $0 \cdot 64$ & $0 \cdot 88$ & $30 \cdot 8$ & $0 \cdot 72$ & X63539 & 7 \\
\hline$r p o C$ & RNA polymerase beta' & $291-$ & $0 \cdot 64$ & $0 \cdot 88$ & $34 \cdot 1$ & 0.66 & U11452 & 8 \\
\hline$d n a K$ & $70 \mathrm{kDa}$ heat-shock protein (Ag 1$)$ & 609 & 0.63 & $0 \cdot 81$ & $38 \cdot 3$ & $0 \cdot 61$ & $\mathrm{X} 58406$ & 9 \\
\hline $\operatorname{rec} A$ & RecA protein & 350 & $0 \cdot 64$ & $0 \cdot 84$ & $35 \cdot 1$ & $0 \cdot 59$ & X58485 & 10 \\
\hline$n r d E$ & Ribonucleotide reductase & 723 & $0 \cdot 59$ & $0 \cdot 85$ & $37 \cdot 2$ & $0 \cdot 63$ & L34407 & 11 \\
\hline$r p s D^{*}$ & Ribosomal protein $\mathrm{S} 4$ & $132-$ & $0 \cdot 63$ & $0 \cdot 80$ & $35 \cdot 5$ & $0 \cdot 63$ & U15140 & 4 \\
\hline$r p o B$ & RNA polymerase beta & 1177 & $0 \cdot 64$ & $0 \cdot 86$ & $34 \cdot 5$ & 0.64 & L27989 & 12 \\
\hline $\operatorname{sod} A$ & Superoxide dismutase (Ag 4) & 207 & $0 \cdot 59$ & $0 \cdot 79$ & $43 \cdot 6$ & 0.63 & X52861 & 13 \\
\hline$g y r B$ & DNA gyrase B & 686 & 0.60 & 0.77 & $41 \cdot 5$ & $0 \cdot 55$ & L.27512 & 14 \\
\hline$c p n 60-1$ & Chaperonin-60-1 & 539 & 0.65 & $0 \cdot 83$ & $38 \cdot 8$ & $0 \cdot 53$ & $\mathrm{X} 60350$ & 15 \\
\hline$r p s G^{*}$ & Ribosomal protein $\mathrm{S} 7$ & 156 & $0 \cdot 63$ & $0 \cdot 78$ & $43 \cdot 7$ & $0 \cdot 57$ & L25882 & 16 \\
\hline$r p s M^{*}$ & Ribosomal protein S13 & 123 & 0.63 & $0 \cdot 77$ & $39 \cdot 2$ & $0 \cdot 61$ & U15140 & 4 \\
\hline keat $G$ & Catalase-peroxidase & 740 & $0 \cdot 65$ & $0 \cdot 82$ & $39 \cdot 8$ & $0 \cdot 58$ & - & 17 \\
\hline$g y r A$ & DNA gyrase A & 838 & $0 \cdot 64$ & $0 \cdot 82$ & $37 \cdot 4$ & 0.58 & L.27512 & 14 \\
\hline$a d b^{*}$ & Alcohol dehydrogenase & 346 & $0 \cdot 65$ & $0 \cdot 87$ & $34 \cdot 2$ & $0 \cdot 59$ & $\mathrm{X} 63450$ & 18 \\
\hline $\operatorname{aroB}$ & 3-Dehydroquinate synthase & 362 & 0.69 & $0 \cdot 87$ & $34 \cdot 2$ & $0 \cdot 60$ & X59509 & 19 \\
\hline$m \operatorname{tr} A$ & Two-component regulator & 225 & $0 \cdot 62$ & $0 \cdot 78$ & $40 \cdot 0$ & $0 \cdot 55$ & U01971 & 20 \\
\hline $\operatorname{inh} A$ & EnvM protein homologue & 269 & $0 \cdot 66$ & $0 \cdot 86$ & $36 \cdot 8$ & $0 \cdot 55$ & U02492 & 21 \\
\hline pol $A$ & DNA polymerase I & 904 & $0 \cdot 68$ & $0 \cdot 87$ & $36 \cdot 3$ & 0.59 & L11920 & 22 \\
\hline $\operatorname{grp} E$ & Heat-shock protein & 235 & $0 \cdot 66$ & $0 \cdot 76$ & $39 \cdot 8$ & $0 \cdot 50$ & X58406 & 9 \\
\hline$a s d^{*}$ & Semialdehyde dehydrogenase & $343+$ & $0 \cdot 69$ & $0 \cdot 88$ & $34 \cdot 3$ & $0 \cdot 56$ & Z18290 & 23 \\
\hline $\arg F^{*}$ & Ornithine carbamoyltransferase & 307 & $0 \cdot 69$ & $0 \cdot 89$ & $33 \cdot 9$ & 0.60 & X64203 & 24 \\
\hline$r p m J^{*}$ & Ribosomal protein L36 & 37 & $0 \cdot 59$ & $0 \cdot 75$ & $41 \cdot 8$ & $0 \cdot 54$ & U15140 & 4 \\
\hline $\operatorname{aro} Q$ & 3-Dehydroquinase & 147 & $0 \cdot 66$ & $0 \cdot 83$ & $40 \cdot 0$ & $0 \cdot 59$ & X59509 & 19 \\
\hline phos & $\begin{array}{l}\text { Phosphate binding protein }(38 \mathrm{kDa} \text {; } \\
\text { Ag 3) }\end{array}$ & 374 & 0.65 & $0 \cdot 82$ & $45 \cdot 4$ & $0 \cdot 53$ & M30046 & 25 \\
\hline $\operatorname{dap} B^{*}$ & Dihydropicolinate reductase & 271 & $0 \cdot 71$ & $0 \cdot 87$ & $34 \cdot 2$ & $0 \cdot 53$ & L24366 & 26 \\
\hline$d n a J$ & Heat-shock protein & $341+$ & $0 \cdot 68$ & $0 \cdot 82$ & $38 \cdot 3$ & $0 \cdot 52$ & X58406 & 9 \\
\hline$m \operatorname{tr} B$ & Two-component sensor & 567 & 0.67 & $0 \cdot 81$ & $41 \cdot 5$ & $0 \cdot 54$ & U14909 & 27 \\
\hline lys $A$ & Diaminopimelate decarboxylase & 446 & $0 \cdot 64$ & $0 \cdot 77$ & $44 \cdot 1$ & 0.54 & M94109 & 28 \\
\hline$b c c A$ & Biotin carboxyl carrier & 654 & 0.68 & $0 \cdot 80$ & $41 \cdot 7$ & $0 \cdot 48$ & Z19549 & 29 \\
\hline ald & L-Alanine dehydrogenase $(\mathrm{Ag} 6)$ & 373 & $0 \cdot 64$ & $0 \cdot 75$ & $44 \cdot 2$ & $0 \cdot 50$ & X63069 & 30 \\
\hline$\ddagger^{*}$ & Mycocerosic acid synthase & 2110 & 0.67 & $0 \cdot 78$ & $42 \cdot 0$ & 0.51 & M95808 & 31 \\
\hline plc & Phospholipase C & 512 & $0 \cdot 63$ & 0.79 & $43 \cdot 3$ & 0.52 & L11868 & 32 \\
\hline $\operatorname{aro} A$ & EPSP synthase & 450 & $0 \cdot 71$ & $0 \cdot 82$ & $38 \cdot 1$ & 0.46 & M62708 & 33 \\
\hline $\operatorname{ura} A^{*}$ & $\begin{array}{l}\text { Orotidine- } 5^{\prime} \text {-monophosphate } \\
\text { decarboxylase }\end{array}$ & 274 & $0 \cdot 73$ & $0 \cdot 85$ & $40 \cdot 5$ & $0 \cdot 46$ & U01072 & 34 \\
\hline
\end{tabular}

* M. bovis sequence.

† References: 1, Ohara et al. (1993b); 2, Baird et al. (1989); 3, Nair et al. (1993); 4, E. Dubnau and others (unpublished); 5, Shinnick (1987); 6, Ohara et al. (1993a); 7, Carlin et al. (1992); 8, M. Rohrbach and others (unpublished); 9, R. Lathigra and others (unpublished); 10, Davis et al. (1991); 11, Yang et al. (1994); 12, Miller et al. (1994); 13, Zhang et al. (1991); 14, Takiff et al. (1994); 15, Kong et al. (1993); 16, F. Silbaq \& H. Berçovier (unpublished); 17, Cockerill et al. (1995); 18, Stelandre et al. (1992); 19, Garbe et al. (1991); 20, R. Curcic \& V. Deretic (unpublished); 21, Banerjee et al. (1994); 22, Mizrahi et al. (1993); 23, Cirillo et al. (1994b); 24, Timm et al. (1992); 25, Andersen \& Hansen (1989); 26, Cirillo et al. (1994a); 27, R. Curcic \& V. Deretic (unpublished); 28, Andersen \& Hansen (1993); 29, Norman et al. (1994); 30, Andersen et al. (1992); 31, Mathur \& Kolattukudy (1992); 32, Leao et al. (1995); 33, Garbe et al. (1990); 34, Aldovini et al. (1993).

$\ddagger$ No gene symbol used by authors. 
Table 2. Codon usage in the $41 \mathrm{M}$. tuberculosis genes listed in Table 1

$N$ number of codons; RSCU, relative synonymous codon usage; ter, termination codon.

\begin{tabular}{|c|c|c|c|c|c|c|c|c|c|c|c|c|c|c|c|}
\hline $\mathbf{A A}$ & Codon & $N$ & RSCU & $\mathbf{A A}$ & Codon & $N$ & RSCU & $\mathbf{A A}$ & Codon & $N$ & RSCU & AA & Codon & $N$ & RSCU \\
\hline \multirow[t]{2}{*}{ Phe } & UUU & 69 & $0 \cdot 28$ & Ser & $\mathrm{UCU}$ & 32 & $0 \cdot 21$ & Tyr & UAU & 80 & 0.43 & Cys & UGU & 35 & $0 \cdot 60$ \\
\hline & UUC & 417 & $1 \cdot 72$ & & UCC & 203 & $1 \cdot 33$ & & UAC & 294 & $1 \cdot 57$ & & UGC & 82 & $1 \cdot 40$ \\
\hline \multirow[t]{2}{*}{ Leu } & UUA & 18 & 0.07 & & UCA & 54 & $0 \cdot 35$ & ter & UAA & 4 & $0 \cdot 32$ & ter & UGA & 22 & 1.74 \\
\hline & UUG & 290 & 1.06 & & UCG & 356 & $2 \cdot 32$ & ter & UAG & 12 & 0.95 & $\operatorname{Trp}$ & UGG & 172 & - \\
\hline \multirow[t]{4}{*}{ Leu } & CUU & 64 & $0 \cdot 23$ & Pro & $\mathrm{CCU}$ & 49 & $0 \cdot 22$ & His & CAU & 96 & $0 \cdot 51$ & Arg & $\mathrm{CGU}$ & 154 & $0 \cdot 76$ \\
\hline & CUC & 262 & 0.96 & & $\mathrm{CCC}$ & 291 & $1 \cdot 30$ & & $\mathrm{CAC}$ & 279 & $1 \cdot 49$ & & CGC & 535 & $2 \cdot 64$ \\
\hline & CUA & 68 & $0 \cdot 25$ & & $\mathrm{CCA}$ & 64 & $0 \cdot 29$ & Gln & CAA & 116 & $0 \cdot 40$ & & CGA & 79 & 0.39 \\
\hline & CUG & 941 & $3 \cdot 44$ & & CCG & 494 & $2 \cdot 20$ & & CAG & 459 & $1 \cdot 60$ & & CGG & 395 & 1.95 \\
\hline \multirow[t]{3}{*}{ Ile } & AUU & 124 & $0 \cdot 46$ & Thr & $\mathrm{ACU}$ & 62 & $0 \cdot 23$ & Asn & $\mathrm{AAU}$ & 74 & $0 \cdot 31$ & Ser & AGU & 52 & 0.34 \\
\hline & $\mathrm{AUC}$ & 668 & $2 \cdot 46$ & & ACC & 682 & $2 \cdot 58$ & & AAC & 410 & 1.69 & & AGC & 222 & $1 \cdot 45$ \\
\hline & AUA & 24 & 0.09 & & $\mathrm{ACA}$ & 43 & $0 \cdot 16$ & Lys & $\mathrm{AAA}$ & 101 & $0 \cdot 30$ & Arg & $\mathrm{AGA}$ & 9 & $0 \cdot 04$ \\
\hline Met & ALG & 321 & - & & ACG & 270 & $1 \cdot 02$ & & AAG & 563 & $1 \cdot 70$ & & AGG & 43 & $0 \cdot 21$ \\
\hline \multirow[t]{4}{*}{ Val } & GUU & 153 & 0.39 & Ala & GCU & 147 & $0 \cdot 30$ & Asp & GAU & 248 & 0.43 & Gly & GGU & 331 & $0 \cdot 82$ \\
\hline & GUC & 618 & $1 \cdot 57$ & & GCC & 937 & $1 \cdot 89$ & & GAC & 911 & $1 \cdot 57$ & & GGC & 854 & $2 \cdot 12$ \\
\hline & GUA & 50 & $0 \cdot 13$ & & GCA & 148 & $0 \cdot 30$ & Glu & GAA & 325 & 0.57 & & GGA & 122 & $0 \cdot 30$ \\
\hline & GUG & 750 & $1 \cdot 91$ & & GCG & 754 & $1 \cdot 52$ & & GAG & 806 & 1.43 & & GGG & 304 & $0 \cdot 75$ \\
\hline
\end{tabular}

clearly homologous to genes known in other species. One advantage of this approach is that for many of the remaining genes homologues have been sequenced from E. coli or B. subtilis, thus allowing comparisons of codon usage among these species. In addition, most partial sequences were excluded from the analysis. As a result, a total of $41 M$. tuberculosis (including $M$. bovis) genes were included (Table 1).

\section{Codon usage in $M$. tuberculosis}

Overall codon usage across these 41 genes is presented in Table 2, which contains a total of 17612 codons. As expected, the overall $\mathrm{G}+\mathrm{C}$-richness of the $M$. tuberculosis genome $(65 \%)$ is reflected in a strong bias towards $\mathrm{C}$ - and G-ending codons for every amino acid. Overall, the $\mathrm{G}+\mathrm{C}$ content values for the first, second and third positions of codons are $67 \%, 45 \%$ and $83 \%$, respectively. The rank order of these values is as expected in a $\mathrm{G}+\mathrm{C}$ rich genome (Osawa et al., 1992). Furthermore, this rank order is consistent across individual genes. For example, the mean value for GC1-GC2 (where GCX is the G+C content at the $X$ th codon position) is 0.22 , with a minimum of 0.09 (in $p l c$ ). The mean value for GC3-GC1 is $0 \cdot 16$ : only one gene $(g r p E$, with a value of $-0 \cdot 004)$ has a value less than 0.05 .

Nevertheless, there is some variation in codon usage patterns among genes (Table 1). This is reflected in GC $3_{\text {S }}$ values, which range from 0.75 to 0.92 (mean 0.83 ), and in $N_{c}$ values, which range from $25 \cdot 1$ to $45 \cdot 4$ (mean $37 \cdot 9$ ). Wright (1990) has suggested plotting $N_{\mathrm{c}}$ values against $\mathrm{GC} 3_{\mathrm{S}}$ as an approach to exploring codon usage variation

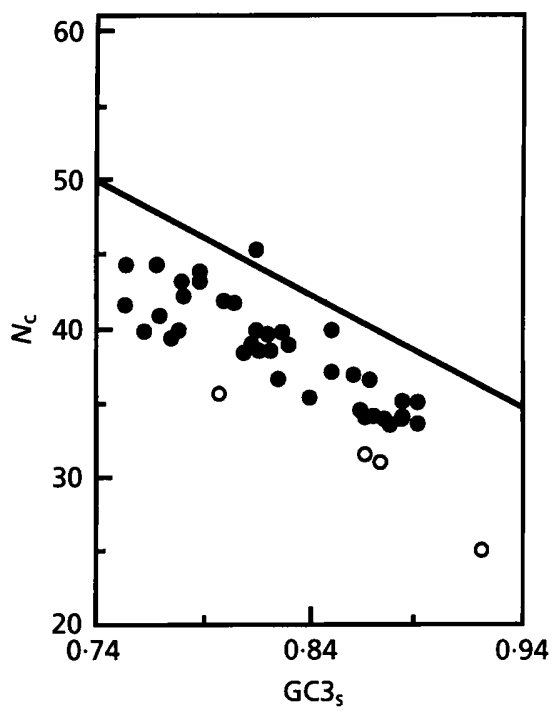

Fig. 1. Effective number of codons used $\left(N_{c}\right)$ in each gene plotted against the $\mathrm{G}+\mathrm{C}$ content at synonymously variable third positions of codons $\left(\mathrm{GC}_{\mathrm{S}}\right)$. The curve represents the expected value of $N_{c}$ if bias is only due to $G+C$ content. The genes represented by open symbols are described in the text.

among genes. For $M$. tuberculosis these values are highly (negatively) correlated (Fig. 1); the correlation coefficient, $r$, is $-0.83(P<0.0001)$. However, such a correlation is expected with high (or low) $\mathrm{GC} 3_{\mathrm{S}}$ values. The curve in Fig. 1 shows the $N_{\mathrm{c}}$ values expected if codon usage is biased only by $\mathrm{G}+\mathrm{C}$ content. Genes furthest away from (below) this curve are those whose codon usage is most biased in other respects. The genes represented by open 


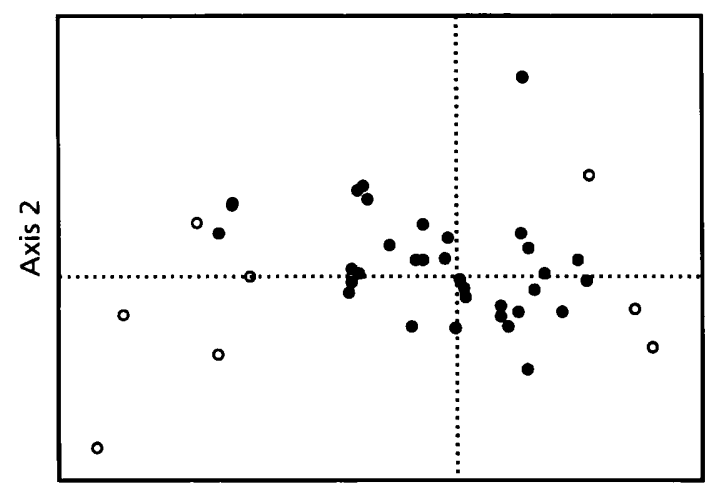

Axis 1

Fig. 2. Correspondence analysis of codon usage variation among $M$. tuberculosis genes. Genes are plotted at their coordinates on the first two axes produced by the analysis, and are listed in Table 1 in their order of appearance on axis 1, from left to right. The genes represented by open symbols to the left are $r p / L$, cpn 10-1, rpsL, cpn60-2 and tuf (with high codon usage bias); those to the right are p/c, aroA and uraA (with low bias).

symbols in Fig. 1 are (from left to right) those encoding ribosomal protein $\mathrm{S} 4(r p s D)$, the GroEL chaperonin homologue (cpn60-2), elongation factor $\mathrm{Tu}(t u f)$, and ribosomal protein $\mathrm{L} 12(r p l L)$, which are all expected to be highly expressed. In fact, the two lowest values of $N_{\mathrm{c}}$ are for the rplL and tuf genes, which in E. coli at least, encode two of the most abundant proteins in the cell.

A more sophisticated approach to explore codon usage variation among genes is correspondence analysis, CA (Greenacre, 1984; Grantham et al., 1981). CA of these 41 genes produced first and second axes accounting for $16 \%$ and $9 \%$ of the total variation, respectively. The fact that the variation along the first axis is nearly twice that for the second is suggestive that there may be a single source of systematic variation among genes. Genes have been plotted according to their positions on the first two axes in Fig. 2. In Table 1, genes are listed in order of their position on axis 1 produced by the CA. Interestingly, all of the genes at one end of axis 1 (at the left in Fig. 2, and at the top of Table 1) are those known or expected to be highly expressed, and which have strong codon usage bias in E. coli and B. subtilis. These tend to be the genes with stronger codon usage bias (as assessed by $N_{\mathrm{c}}$ values) in $M$. tuberculosis: position on axis 1 and $N_{\mathrm{c}}$ values are correlated $(r=0.61, P<0.001)$. In addition, the genes at the other extreme of axis 1 are those known or expected to be expressed at low levels (e.g. ura $A$ and aro $A$ ), and whose $E$. coli or $B$. subtilis homologues have low codon usage bias. Thus, it appears that the first axis produced by CA is differentiating among genes according to codon usage differences associated with gene expression level.

To elucidate the differences between genes at the two extremes of axis 1 , we have compiled (Table 3 ) codon usage values for two subsets of genes: tuf, $r p l L, r p s L$, cpn10-1 and cpn60-2 (representing the high bias/ expression extreme; total 1295 codons) and aro $A$, plc and ura $A$ (representing the low bias/expression extreme; total 1613 codons); these genes are shown by open symbols in Fig. 2. Codon frequencies (within amino acids) in these two groups were contrasted using a heterogeneity chi-square test, taking $P<0.01$ as the criterion of significance due to the large number of tests performed: 10 codons, for 10 different amino acids, are used significantly more often in the 'high' genes than in the 'low' genes. A further 7 codons are more frequently used, but give chi-square values with probabilities in the range $0 \cdot 01-0 \cdot 10$. These include UUC, AUC and AAC, which have been found to be the optimal codons for Phe, Ile and Asn, respectively, in a wide range of species (Sharp et al., 1988; Sharp \& Devine, 1989). In each case, the codon is very heavily used in the 'high' group, but the chi-square value is not significant because of the relatively high usage in the 'low' group. As more sequences become available, these differences may become significant. We tentatively designate all 17 of these codons (for 15 amino acids) as 'optimal' codons, to calculate the frequency of optimal codons $\left(F_{\mathrm{op}}\right)$ in each gene, since using only the codons with significant values would cover only about half of the genetic code. (In Table 3, these 17 codons are indicated in bold, with * marking the 10 codons with $P<0 \cdot 01$.) In a gene with the same amino acid composition as the total data set (Table 2), and in which codon usage were simply determined by a $\mathrm{G}+\mathrm{C}$ content at silent sites of $83 \%$, the $F_{\text {op }}$ value would be about 0.55 . The observed $F_{\text {op }}$ values range between 0.46 and 0.84 . These values ought to be correlated with position on axis 1 , and indeed the high value of this correlation $(0.90)$ indicates that this is a reasonably succinct summary of the spread along this axis. No simple codon usage statistic was found to be correlated with the second or subsequent axes.

For 35 of the 41 genes chosen for our analysis, the sequence of a homologue is available from either E. coli or $B$. subtilis (or both). The strength of species-specific codon usage bias in the E. coli and B. subtilis genes has been estimated using the codon adaptation index (CAI; Sharp \& Li, 1987; Shields \& Sharp, 1987), and is compared to the $F_{\text {op }}$ values for the M. tuberculosis genes in Table 4. $M$. tuberculosis expresses two homologues of GroEL, now called chaperonin 60 (Kong et al., 1993). One gene lies in an operon with the groES homologue, and one is located elsewhere; these have been termed cpn60-1 and cpn60-2, respectively (Coates et al., 1993). A great deal of research has been directed at a $65 \mathrm{kDa}$ antigen (antigen 2), which is the product of the cpn60-2 gene, but not at the product of the cpn60-1 gene. This may indicate that $c p n 60-2$ is more highly expressed than $c p n 60-1$, and the $F_{\text {op }}$ value for cpn60-2 (0.73) is rather higher than that for $c p n 60-1(0.53)$. Since groEL has strong codon usage bias in $E$. coli and $B$. subtilis, this may indicate that cpn60-2 rather than $c p n 60-1$ is the functional homologue of groEL, even though it is cpn60-1 that is found in an operon with the groES homologue. Excluding cpn60-1, the correlation of CAI and $F_{\text {op }}$ is 0.56 for E. coli (32 genes) and 0.61 for B. subtilis (24 genes). Considering only 22 genes that can be compared among all three species, the correlation 
Table 3. Codon usage in $M$. tuberculosis genes with high and low expression levels

See text and Fig. 2 for further details.

\begin{tabular}{|c|c|c|c|c|c|c|c|c|c|c|c|}
\hline \multirow[t]{2}{*}{$\mathbf{A A}$} & \multirow[t]{2}{*}{ Codon } & \multicolumn{2}{|c|}{ High } & \multicolumn{2}{|c|}{ Low } & \multirow[t]{2}{*}{$\mathbf{A A}$} & \multirow[t]{2}{*}{ Codon } & \multicolumn{2}{|c|}{ High } & \multicolumn{2}{|c|}{ Low } \\
\hline & & $N$ & RSCU & $N$ & RSCU & & & $N$ & RSCU & $N$ & RSCU \\
\hline Phe & UUU & 1 & $0 \cdot 08$ & 10 & $0 \cdot 40$ & Ser & UCU & 1 & $0 \cdot 15$ & 1 & 0.07 \\
\hline Phe & UUC & 25 & $1 \cdot 92$ & 40 & $1 \cdot 60$ & Ser & UCC & 17 & $2 \cdot 62$ & 20 & $1 \cdot 40$ \\
\hline Leu & UUA & 0 & 0.00 & 4 & $0 \cdot 15$ & Ser & UCA & 0 & $0 \cdot 00$ & 12 & $0 \cdot 84$ \\
\hline Leu & UUG & 8 & 0.44 & 37 & $1 \cdot 39$ & Ser & UCG & 13 & $2 \cdot 00$ & 30 & $2 \cdot 09$ \\
\hline Leu & CUU & 2 & $0 \cdot 11$ & 8 & $0 \cdot 30$ & Pro & $\mathrm{CCU}$ & 4 & 0.31 & 5 & $0 \cdot 16$ \\
\hline Leu & CUC & 22 & $1 \cdot 21$ & 19 & 0.71 & Pro & $\mathrm{CCC}$ & 15 & $1 \cdot 18$ & 49 & 1.59 \\
\hline Leu & CUA & 1 & 0.06 & 9 & $0 \cdot 34$ & Pro & CCA & 4 & $0 \cdot 31$ & 11 & 0.36 \\
\hline Leu & CUG* & 76 & $4 \cdot 18$ & 83 & $3 \cdot 11$ & Pro & CCG & 28 & $2 \cdot 20$ & 58 & 1.89 \\
\hline Ile & AUU & 10 & 0.45 & 15 & $0 \cdot 75$ & Thr & $\mathrm{ACU}$ & 2 & 0.09 & 5 & $0 \cdot 18$ \\
\hline Ile & AUC & 57 & $2 \cdot 55$ & 43 & $2 \cdot 15$ & Thr & ACC* & 75 & $3 \cdot 26$ & 68 & $2 \cdot 47$ \\
\hline Ile & AUA & 0 & 0.00 & 2 & $0 \cdot 10$ & Thr & $\mathrm{ACA}$ & 3 & $0 \cdot 13$ & 6 & 0.22 \\
\hline Met & AUG & 21 & - & 29 & - & Thr & ACG & 12 & 0.52 & 31 & $1 \cdot 13$ \\
\hline $\mathrm{Val}$ & GUU & 17 & 0.49 & 11 & 0.32 & Ala & GCU & 12 & 0.33 & 14 & $0 \cdot 25$ \\
\hline Val & GUC & 70 & $2 \cdot 00$ & 48 & $1 \cdot 40$ & Ala & GCC* & 84 & $2 \cdot 30$ & 96 & $1 \cdot 73$ \\
\hline Val & GUA & 4 & $0 \cdot 11$ & 5 & $0 \cdot 15$ & Ala & GCA & 7 & 0.19 & 30 & 0.54 \\
\hline Val & GUG & 49 & $1 \cdot 40$ & 73 & $2 \cdot 13$ & Ala & GCG & 43 & $1 \cdot 18$ & 82 & 1.48 \\
\hline Tyr & UAU & 0 & 0.00 & 10 & 0.63 & Cys & UGU & 0 & 0.00 & 4 & 0.47 \\
\hline Tyr & UAC* & 22 & $2 \cdot 00$ & 22 & $1 \cdot 38$ & Cys & UGC & 1 & $2 \cdot 00$ & 13 & 1.53 \\
\hline ter & UAA & 0 & - & 0 & - & ter & UGA & 2 & - & 3 & - \\
\hline ter & UAG & 3 & - & 1 & - & $\operatorname{Trp}$ & UGG & 3 & - & 22 & - \\
\hline His & $\mathrm{CAU}$ & 0 & 0.00 & 11 & 0.73 & Arg & CGU* & 14 & $1 \cdot 29$ & 7 & 0.42 \\
\hline His & CAC* & 15 & $2 \cdot 00$ & 19 & $1 \cdot 27$ & Arg & CGC & 35 & $3 \cdot 23$ & 37 & $2 \cdot 24$ \\
\hline Gln & CAA & 2 & $0 \cdot 11$ & 15 & 0.60 & Arg & CGA & 1 & 0.09 & 10 & 0.61 \\
\hline Gln & CAG* & 36 & 1.89 & 35 & 1.40 & Arg & CGG & 15 & $1 \cdot 38$ & 39 & $2 \cdot 36$ \\
\hline Asn & $\mathrm{AAU}$ & 2 & $0 \cdot 11$ & 9 & 0.41 & Ser & $\mathrm{AGU}$ & 2 & 0.31 & 1 & 0.07 \\
\hline Asn & AAC & 34 & 1.89 & 35 & 1.59 & Ser & $\mathrm{AGC}$ & 6 & 0.92 & 22 & 1.53 \\
\hline Lys & AAA & 4 & 0.08 & 8 & 0.64 & Arg & AGA & 0 & 0.00 & 3 & $0 \cdot 18$ \\
\hline Lys & AAG* & 100 & 1.92 & 17 & $1 \cdot 36$ & Arg & AGG & 0 & $0 \cdot 00$ & 3 & $0 \cdot 18$ \\
\hline Asp & GAU & 11 & 0.29 & 16 & 0.39 & Gly & GGU* & 39 & $1 \cdot 32$ & 28 & 0.65 \\
\hline Asp & GAC & 66 & $1 \cdot 71$ & 67 & $1 \cdot 61$ & Gly & GGC & 68 & $2 \cdot 31$ & 89 & $2 \cdot 06$ \\
\hline Glu & GAA & 16 & 0.27 & 25 & 0.88 & Gly & GGA & 5 & 0.17 & 16 & 0.37 \\
\hline Glu & GAG* & 104 & 1.73 & 32 & $1 \cdot 12$ & Gly & GGG & 6 & 0.20 & 40 & 0.92 \\
\hline
\end{tabular}

coefficients are: $0.65(M$. tuberculosis vs $E$. coli), $0.58(M$. tuberculosis vs $B$. subtilis), and 0.65 (E. coli vs. B. subtilis).

\section{Codon usage in an intein}

The $\operatorname{rec} A$ gene of $M$. tuberculosis (Davis et al., 1991) is interesting because it contains an insertion encoding an intein (Perler et al., 1994), i.e. the primary translation product is subject to protein splicing. In our initial analysis the part of the sequence encoding this intein was excluded. Codon usage in the intein is different from that in the 'extein' (i.e. the codons for the mature RecA protein): the intein is less $\mathrm{G}+\mathrm{C}$-rich $\left(\mathrm{GC} 3_{\mathrm{S}}=0.70\right)$, and has a lower $F_{\text {op }}(0.50)$. Inteins appear to be mobile elements. For example, while the $M$. leprae $\operatorname{rec} A$ also contains an intein, it is highly divergent from that in $M$. tuberculosis and located at a different position (Davis et al., 1994). Thus, the intein may not have been present in the $M$. tuberculosis $\operatorname{rec} A$ gene long enough for its codon usage to be selected to as high a level of bias as in the extein.

\section{DISCUS SION}

M. tuberchiosis genes predominantly use $\mathrm{C}$ - and $\mathrm{G}$-ending codons, presumably because of a $\mathrm{G}+\mathrm{C}$-biased mutation pattern in this species. Nevertheless, codon usage varies among $M$. tuberculosis genes. The primary source of variation is in the use of a subset of codons, which we have tentatively concluded are the translationally optimal codons in this species, since their frequency appears to be 
Table 4. Codon usage bias in homologues

\begin{tabular}{|c|c|c|c|c|c|}
\hline \multicolumn{2}{|c|}{ E. coli } & \multicolumn{2}{|c|}{ B. subtilis* } & \multicolumn{2}{|c|}{ M. tuberculosis } \\
\hline Gene & CAI & Gene & CAI & Gene & $F_{\text {op }}$ \\
\hline rplL & $0 \cdot 81$ & $(r p / L$ & $0 \cdot 80)$ & $r p l L$ & $0 \cdot 84$ \\
\hline groEL & 0.79 & groEL & 0.69 & $\operatorname{cpn} 60-2$ & 0.73 \\
\hline$t u f B$ & 0.79 & - & - & tuf & 0.72 \\
\hline groES & $0 \cdot 51$ & groEs & 0.63 & $\operatorname{cpn} 10-1$ & $0 \cdot 70$ \\
\hline $\inf A$ & $0 \cdot 48$ & $\inf A$ & 0.59 & $\inf A$ & 0.68 \\
\hline$r p o C$ & $0 \cdot 68$ & $(r p o C$ & $0 \cdot 62)$ & $r p o C$ & $0 \cdot 66$ \\
\hline$r p s L$ & 0.66 & - & - & $r p s L$ & 0.65 \\
\hline$r p o B$ & 0.63 & $r p o B$ & 0.55 & $r p o B$ & 0.64 \\
\hline$r p s D$ & 0.57 & $r p s D$ & 0.62 & $r p s D$ & 0.63 \\
\hline $\operatorname{sod} A / B$ & $0 \cdot 71 / 0.55$ & - & - & $\operatorname{sod} A$ & $0 \cdot 63$ \\
\hline$r p s M$ & $0 \cdot 45$ & $r p s M$ & 0.76 & $r p s M$ & $0 \cdot 61$ \\
\hline$d n a K$ & 0.72 & dnaK & 0.66 & $d n a K$ & $0 \cdot 61$ \\
\hline$r p s s$ & 0.46 & $\operatorname{rps} S$ & 0.57 & $r p s S$ & 0.61 \\
\hline $\operatorname{tbr} A$ & $0 \cdot 31$ & dapG & $0 \cdot 40$ & ask & $0 \cdot 61$ \\
\hline $\operatorname{aro} B$ & $0 \cdot 28$ & $\operatorname{aro} B$ & 0.39 & $\operatorname{aroB}$ & 0.60 \\
\hline $\arg F$ & $0 \cdot 36$ & $\arg F$ & $0 \cdot 37$ & $\operatorname{argF}$ & 0.60 \\
\hline pol $A$ & $0 \cdot 39$ & - & - & pol $A$ & 0.59 \\
\hline $\operatorname{rec} A$ & 0.61 & recE & $0 \cdot 49$ & $\operatorname{rec} A$ & 0.59 \\
\hline $\operatorname{mur} A$ & 0.32 & - & - & $a d b$ & 0.59 \\
\hline $\operatorname{gyr} A$ & 0.52 & $\operatorname{gyr} A$ & $0 \cdot 50$ & $\operatorname{gyr} A$ & 0.58 \\
\hline kat $G$ & 0.51 & - & - & kat $G$ & 0.58 \\
\hline $\operatorname{rps} G$ & $0 \cdot 61$ & - & - & $r p s G$ & 0.57 \\
\hline usg & $0 \cdot 44$ & asd & 0.51 & asd & $0 \cdot 56$ \\
\hline envM & $0 \cdot 60$ & - & - & $\operatorname{inh} A$ & 0.55 \\
\hline $\operatorname{gyr} B$ & 0.55 & $g y r B$ & 0.47 & $g y r B$ & 0.55 \\
\hline$r p m J$ & $0 \cdot 46$ & $r p m J$ & 0.76 & $r p m J$ & $0 \cdot 54$ \\
\hline lys $A$ & $0 \cdot 33$ & lys $A$ & $0 \cdot 48$ & $l_{s} A$ & $0 \cdot 54$ \\
\hline groEL & 0.79 & groEL & 0.69 & $\operatorname{cpn} 60-1$ & 0.53 \\
\hline phos & 0.58 & - & - & phos & 0.53 \\
\hline$d a p B$ & 0.34 & $d a p B$ & 0.48 & $d a p B$ & $0 \cdot 53$ \\
\hline$d n a J$ & $0 \cdot 51$ & $d n a J$ & $0 \cdot 49$ & $d n a J$ & 0.52 \\
\hline- & - & $\operatorname{grp} E$ & 0.46 & $\operatorname{grp} E$ & $0 \cdot 50$ \\
\hline- & - & ald & 0.45 & ald & 0.50 \\
\hline$f a b G$ & $0 \cdot 56$ & - & - & $b c c A$ & $0 \cdot 48$ \\
\hline $\operatorname{aro} A$ & $0 \cdot 36$ & aroE & 0.43 & $\operatorname{aro} A$ & 0.46 \\
\hline
\end{tabular}

* Values in parentheses indicate that the gene sequence is incomplete.

correlated with gene expression level. One indirect way to examine whether the $F_{\text {op }}$ (frequency of optimal codons) values for $M$. tuberculosis relate well to gene expression level is to compare them to codon bias values for homologues from E. coli and B. subtilis, where the link between codon usage bias and gene expression level is quite well established. (This is making the assumption that many genes will be expressed at similar levels in different bacterial species.) The $M$. tuberculosis values are approximately as well correlated with CAI values in E. coli and $B$. subtilis as the latter two are with each other. We conclude that the differentiation in codon usage among $M$. tuberculosis genes is most likely due to selection for optimal codons being more effective on genes expressed at higher levels. However, the extent of heterogeneity among genes in $M$. tuberculosis is rather lower than in $E$. coli and $B$. subtilis, which may reflect weaker selection in M. tuberculosis due to its long generation time.

Among the 17 codons identified above as likely to be translationally optimal, 15 end in $C$ or G. Among these, UUC, UAC and AAC belong to two codon families read (in both E. coli and B. subtilis) by a single tRNA with guanosine or a modified guanosine in the first position of the anticodon. Such tRNAs can bind to U-ending codons using wobble interactions, but the standard WatsonCrick basepairing with a $\mathrm{C}$-ending codon seems to be faster and more stable (Labuda et al., 1982; Thomas et al., 1988; Curran \& Yarus, 1989). This would explain why these codons are preferred in a wide range of species. For other amino acids (e.g. Val and Ala), the preferred codons in M. tuberculosis differ from those in E. coli and B. subtilis. This presumably reflects a difference among these species in their tRNA populations. In the short term, codon usage is selected to match the tRNAs available. But in the long term, under sustained mutation pressure towards $G+C$ (or A + T), tRNA populations should eventually adapt to match the most prevalent codons (Shields, 1990). Thus, persistent mutation bias towards $\mathrm{G}+\mathrm{C}$-richness in $M$. tuberculosis may have forced changes in the expression level of tRNAs, or even substitutions in the anticodons of tRNA genes. The exceptions to this trend are the Uending codons for Arg and Gly; interestingly, these also appear to be the preferred codons in a wide range of species (Sharp et al., 1988; Sharp \& Devine, 1989).

To investigate how codon usage patterns evolve, it is necessary to compare more closely related species, i.e. to compare $M$. tuberculosis with other high-G +C Grampositive bacteria. Honore et al. (1993) compiled codon usage values for the 12 ORFs in $M$. leprae cosmid B1790. The relative values are not dissimilar to those for $M$. tuberculosis (Table 2), even though the $M$. leprae genome is significantly more A + T-rich $(57 \% \mathrm{G}+\mathrm{C})$. They found a third codon position $\mathrm{G}+\mathrm{C}$ content of $75 \%$ (compared to $83 \%$ here for $M$. tuberculosis). Given the $8 \%$ difference in genomic $\mathrm{G}+\mathrm{C}$ content, third positions of codons would be expected to differ by rather more than $8 \%$ between the two species. This anomaly would appear to be due to the particular genes present in the $M$. leprae cosmid. Five encode ribosomal proteins, two encode elongation factors, and two encode RNA polymerase subunits; thus, nine of the 12 ORFs are expected to be highly expressed. By simply asking how many of the 61 sense codons were not used in each gene, Honore $e$ t al. (1993) found evidence that the degree of bias varied among the ORFs in the cosmid. Thus, the compiled codon usage for these 12 ORFs may be somewhat atypical, and a more random set of genes may be less $G+C$-rich at silent sites.

The genera Nocardia and Corynebacterium are quite closely related to Mycobacterium (Olsen et al., 1994). Coque et al. (1993) examined codon usage in a small data set (14 ORFs) from Nocardia lactamdurans. This species appears to be very $\mathrm{G}+\mathrm{C}$-rich: although genomic $\mathrm{G}+\mathrm{C}$ content was not given, for $27.6 \mathrm{~kb}$ of sequence analysed the value was 
$70 \%$. GC3 $3_{\mathrm{S}}$ values were found to be very high and to only vary between 0.91 and 0.97 . Thus, $N$. lactamdurans seems to be similar to Micrococcus luteus (Ohama et al., 1990) and Streptomyces species (Wright \& Bibb, 1992), where codon usage varies little among genes and is largely dominated by $G+C$-richness.

Codon usage in Corynebacterium glutamicum (genomic $\mathrm{G}+\mathrm{C}$ content $53 \%$ ) has been examined in a little more detail. Eikmanns (1992) found more biased codon usage values in a set of five highly expressed genes (mainly encoding glycolytic enzymes) than in 15 genes involved in amino acid biosynthesis and expected to be expressed at only moderate levels. Malumbres et al. (1993) combined data from C. glutamicum and Brevibacterium lactofermentum (which they showed from sequence comparisons to be extremely closely related, if not the same species) to yield a data set of 34 genes, among which seven were represented twice (i.e. both the $C$. glutamicum and the $B$. lactofermentum copies were included). The $12 \%$ difference in genomic $\mathrm{G}+\mathrm{C}$ content between $C$. glutamicum and $M$. tuberculosis is reflected in overall codon usage: the average $\mathrm{GC}_{\mathrm{s}}$ among the $34 \mathrm{C}$. glutamicum genes is 0.62 (Malumbres et al., 1993), compared to 0.83 for $M$. tuberculosis. Eikmanns (1992) and Malumbres et al. (1993) both defined the 'preferred' codons for $C$. glutamicum, but neither took account of whether the codon was significantly more frequently used in highly expressed genes. However, all but one of the 17 codons designated here as optimal in $M$. tuberculosis appear among the 'preferred' codons in C. glutamicum. The exception is GCC: the preferred codon(s) for Ala in C. glutamicum is GCA (and perhaps GCU). In addition, for Pro the preferred codon(s) in C. glutamicum is CCA (and perhaps CCU); while we did not designate an optimal codon for Pro, neither CCA nor CCU is used at high frequency in highly expressed $M$. tuberculosis genes (Table 3). In both cases, the difference is consistent with the divergence in genomic $\mathrm{G}+\mathrm{C}$ content between the two species. Overall, the subset of synonymous codons which appear to be selected for in the two species has diverged very little.

\section{ACKNOWLEDGEMENTS}

We thank Staffan Bergh, Jeremy Dale and Frank Wright for discussion, and Charles G. Kurland for his support. This work was financed by grants from the EC Human Capital and Mobility Program (contract CHRX-CT93-0169), the Natural Sciences Research Council, the Swedish Cancer Society, and the Knud and Alice Wallennberg Foundation.

\section{REFERENCES}

Aldovini, A., Husson, R. N. \& Young, R. A. (1993). The ura $A$ locus and homologous recombination in Mycobacterium bovis BCG. $J$ Bacteriol 175, 7282-7289.

Altschul, S. F., Gish, W., Miller, W., Myers, E. W. \& Lipman, D. J. (1990). Basic local alignment search tool. J Mol Biol 215, 403-410.

Andersen, A. B. \& Hansen, E. B. (1989). Structure and mapping of antigenic domains of protein antigen $\mathrm{b}$, a 38,000-molecular-weight protein of Mycobacterium tuberculosis. Infect Immun 57, 2481-2488.
Andersen, A. B. \& Hansen, E. B. (1993). Cloning of the lys $A$ gene from Mycobacterium tuberculosis. Gene 124, 105-109.

Andersen, A. B., Andersen, P. \& Ljungqvist, L. (1992). Structure and function of a 40,000-molecular-weight protein antigen of Mycobacterium tuberculosis. Infect Immun 60, 2317-2323.

Andersson, S. G. E. \& Kurland, C. G. (1990). Codon preferences in free-living microorganisms. Microbiol Rev 54, 198-210.

Baird, P. N., Hall, L. M. C. \& Coates, A. R. M. (1989). Cloning and sequence analysis of the $10 \mathrm{kDa}$ antigen gene of Mycobacterium tuberculosis. J Gen Microbiol 135, 931-939.

Banerjee, A., Dubnau, E., Quemard, A., Balasubramanian, V., Um, K. S., Wilson, T., Collins, D., de Lisle, G. \& Jacobs, W. R., Jr (1994). inh $A$, a gene encoding a target for isoniazid and ethionamide in Mycobacterium tuberculosis. Science 263, 227-230.

Bergh, S. \& Cole, S. T. (1994). MycDB: an integrated mycobacterial database. Mol Microbiol 12, 517-534.

Bloom, B. R. \& Murray, C. J. L. (1992). Tuberculosis - commentary on a reemergent killer. Science 257, 1055-1064.

Carlin, N. I., Lofdahl, S. \& Magnusson, M. (1992). Monoclonal antibodies specific for elongation factor $\mathrm{Tu}$ and complete nucleotide sequence of the tuf gene in Mycobacterium tuberculosis. Infect Immun 60, 3136-3142.

Cirillo, J. D., Weisbrod, T. R., Banerjee, A., Bloom, B. R. \& Jacobs, W. R., Jr (1994a). Genetic determination of the mesodiaminopimelate biosynthetic pathway of mycobacteria. $J$ Bacteriol 176, 4424-4429.

Cirillo, J. D., Weisbrod, T. R., Pascopella, L., Bloom, B. R. \& Jacobs, W. R., Jr (1994b). Isolation and characterization of the aspartokinase and aspartate semialdehyde dehydrogenase operon from mycobacteria. Mol Microbiol 11, 629-639.

Coates, A. R. M., Shinnick, T. M. \& Ellis, R. J. (1993). Chaperonin nomenclature. Mol Microbiol 8, 787.

Cockerill, F. R., Uhl, J. R., Temesgen, Z., Zhang, Y., Stockman, L., Roberts, G. D., Williams, D. L. \& Kline, B. C. (1995). Rapid identification of a point mutation of the Mycobacterium tuberculosis catalase-peroxidase $(k a t G)$ gene associated with isoniazid resistance. $J$ Infect Dis 171, 240-245.

Collins, M. E., Patki, A., Wall, S., Nolan, A., Goodger, J., Woodward, M. J. \& Dale, J. W. (1990). Cloning and characterization of the gene for the ' $19 \mathrm{kDa}$ ' antigen of Mycobacterium bovis. J Gen Microbiol 136, 1429-1436.

Coque, J.-J. R., Malumbres, M., Martin, J. F. \& Liras, P. (1993). Analysis of the codon usage of the cephamycin C producer Nocardia lactamdurans. FEMS Microbiol Lett 110, 91-96.

Curran, J. F. \& Yarus, M. (1989). Rates of aa-tRNA selection at 29 sense codons in vivo. $J$ Mol Biol 209, 65-77.

Davis, E. O., Sedgwick, S. G. \& Colston, M. J. (1991). Novel structure of the $\operatorname{rec} A$ locus of Mycobacterium tuberculosis implies processing of the gene product. J Bacteriol 173, 5653-5662.

Davis, E. O., Thangaraj, H. S., Brooks, P. C. \& Colston, M. J. (1994). Evidence of selection for protein introns in the $\operatorname{rec} A$ s of pathogenic mycobacteria. EMBO J 13, 699-703.

Eikmanns, B. J. (1992). Identification, sequence analysis, and expression of a Corynebacterium glutamicum gene cluster encoding the three glycolytic enzymes glyceraldehyde-3-phosphate dehydrogenase, 3-phosphoglycerate kinase, and triose phosphate isomerase. $J$ Bacteriol 174, 6076-6086.

Garbe, T., Jones, C., Charles, I., Dougan, G. \& Young, D. B. (1990). Cloning and characterization of the aro $A$ gene from Mycobacterium tuberculosis. J Bacteriol 172, 6774-6782.

Garbe, T., Servos, S., Hawkins, A., Dimitriadis, G., Young, D., 
Dougan, G. \& Charles, I. (1991). The Mycobacterium tuberculosis shikimate pathway genes: evolutionary relationship between biosynthetic and catabolic 3-dehydroquinases. Mol $\mathcal{E}$ Gen Genet 228, 385-392.

Gouy, M. \& Gautier, C. (1982). Codon usage in bacteria: correlation with gene expressivity. Nucleic Acids Res 10, 7055-7074.

Gouy, M., Gautier, C., Attimonelli, M., Lanave, C. \& Di Paola, G. (1985). ACNUC-a portable retrieval system for nucleic acid sequence databases: logical and physical designs and usage. Comput Appl Biosci 1, 167-172.

Grange, J. M, Gibson, J., Osborn, T. W., Collins, C. H. \& Yates, M. D. (1983). What is BCG? Tubercle 64, 129-139,

Grantham, R., Gautier, C., Gouy, M., Jacobzone, M. \& Mercier, R. (1981). Codon catalog usage is a genomic strategy modulated for gene expressivity. Nucleic Acids Res 9, r43-r74.

Greenacre, M. J. (1984). Theory and Applications of Correspondence Analysis. London: Academic Press.

Hall, B. G. \& Sharp, P. M. (1992). Molecular population genetics of Escherichia coli: DNA sequence diversity at the $c e l C$, crr, and gutB loci of natural isolates. Mol Biol Evol 9, 654 665.

Holm, L. (1986). Codon usage and gene expression. Nucleic Acids Res 14, 3075-3087.

Honore, N., Bergh, S., Chanteau, S., Doucet-Populaire, F., Eiglmeier, K., Garnier, T., Georges, C., Launois, P., Limpaiboon, T., Newton, S., Niang, K., del Portillo, P., Ramesh, G. R., Reddi, P., Ridel, P. R., Sittisombut, N., Wu-Hunter, S. \& Cole, S. T. (1993). Nucleotide sequence of the first cosmid from the Mycobacterium leprae genome project: structure and function of the Rif-Str regions. Mol Microbiol 7, 207-214.

Ikemura, T. (1981). Correlation between the abundance of Escherichia coli transfer RNAs and the occurrence of the respective codons in its protein genes: a proposal for a synonymous codon choice that is optimal for the E. coli translational system. $J$ Mol Biol 151, 389-409.

Kong, T. H., Coates, A. R. M., Butcher, P. D., Hickman, C. J. \& Shinnick, T. M. (1993). Mycobacterium tuberculosis expresses two chaperonin-60 homologs. Proc Natl Acad Sci US A 90, 2608-2612.

Labuda, D., Grosjean, H., Striker, G. \& Porschke, D. (1982).

Codon-anticodon and anticodon-anticodon interaction - evaluation of equilibrium and kinetic parameters of complexes involving a G-U wobble. Biocbim Biophys Acta 698, 230-236.

Leao, S. C., Rocha, C. L., Murillo, L. A., Parra, C. A. \& Patarroyo, M. E. (1995). A species-specific nucleotide sequence of Mycobacterium tuberculosis encodes a protein that exhibits hemolytic activity when expressed in Eschericbia coli. Infect Immun 63, 4301-4306.

Lloyd, A. T. \& Sharp, P. M. (1992). codons: a microcomputer program for codon usage analysis. $J$ Hered 83, 239-240.

Malumbres, M., Gil, J. A. \& Martin, J. F. (1993). Codon preference in corynebacteria. Gene 134, 15-24.

Mathur, M. \& Kolattukudy, P. E. (1992). Molecular cloning; and sequencing of the gene for mycocerosic acid synthase, a novel fatty acid elongating multifunctional enzyme, from Mycobacterium tuberculosis var. bovis Bacillus Calmette-Guerin. J Biol Chem 267, $19388-19395$.

Medigue, C., Rouxel, T., Vigier, P., Henaut, A. \& Danchin, A. (1991). Evidence for horizontal gene transfer in Escbericbia coli speciation. J Mol Biol 222, 851-856.

Merino, E., Balbas, P., Puente, J. L. \& Bolivar, F. (1994). Antisense overlapping open reading frames in genes from bacteria to hurnans. Nucleic Acids Res 22, 1903-1908.

Miller, L. P., Crawford, J. T. \& Shinnick, T. M. (1994). The $r p o B$ gene of Mycobacterium tuberculosis. Antimicrob Agents Chemother 38, 805-811.

Mizrahi, V., Huberts, P., Dawes, S. S. \& Dudding, L. R. (1993). A PCR method for the sequence analysis of the $\operatorname{gyr} A, \operatorname{pol} A$ and $r n h A$ gene segments from mycobacteria. Gene 136, 287-290.

Nair, J., Rouse, D. A., Bai, G. H. \& Morris, S. L. (1993). The $r p s L$ gene and streptomycin resistance in single and multiple drugresistant strains of Mycobacterium tuberculosis. Mol Microbiol 10, 521-527.

Norman, E., De Smet, K. A., Stoker, N. G., Ratledge, C., Wheeler, P. R. \& Dale, J. W. (1994). Lipid synthesis in mycobacteria: characterization of the biotin carboxyl carrier protein genes from Mycobacterium leprae and M. tuberculosis. J Bacteriol 176, 2525-2531.

O'Connor, S. P., Rumschlag, H. S. \& Mayer, L. W. (1990). Nucleotide sequence of the gene encoding the $35-\mathrm{kDa}$ protein of Mycobacterium tuberculosis. Res Microbiol 141, 407-423.

Ohama, T., Muto, A. \& Osawa, S. (1990). Role of GC-biased mutation pressure on synonymous codon choice in Micrococcus luteus, a bacterium with a high genomic GC-content. Nucleic Acids Res 18, 1565-1569.

Ohara, N., Kimura, M., Higashi, Y. \& Yamada, T. (1993a). Isolation and amino acid sequence of the $30 \mathrm{~S}$ ribosomal protein S19 from Mycobacterium bovis BCG. FEBS Lett 331, 9-14.

Ohara, N., Kimura, M., Wada, N. \& Yamada, T. (1993b). Cloning and sequencing of the gene encoding the ribosomal L7/L12-like protein of Mycobacterium bovis BCG. Nucleic Acids Res 21, 3579.

Ohkubo, S., Muto, A., Kawauchi, Y., Yamao, F. \& Osawa, S. (1987). The ribosomal protein gene cluster of Mycoplasma capricolum. Mol \& Gen Genet 210, 314-322.

Olsen G. J., Woese, C. R. \& Overbeek, R. (1994). The winds of (evolutionary) change: breathing new life into microbiology. $J$ Bacteriol 176, 1-6.

Osawa, S., Jukes, T. H., Watanabe, K. \& Muto, A. (1992). Recent evidence for evolution of the genetic code. Microbiol Rev 56, 229-264.

Perler, F. B., Davis, E. O., Dean, G. E., Gimble, F. S., Jack, W. E., Neff, N., Noren, C. J., Thorner, J. \& Belfort, M. (1994). Proteinsplicing elements: inteins and exteins - a definition of terms and recommended nomenclature. Nucleic Acids Res 22, 1125-1127.

Plunkett, G., III, Burland, V., Daniels, D. L. \& Blattner, F. R. (1993). Analysis of the Eschericbia coli genome. III. DNA sequence of the region from 87.2 to $89 \cdot 2$ minutes. Nucleic Acids Res 21, 3391-3398.

Sharp, P. M. (1985). Does the 'non-coding' strand code? Nucleic Acids Res 13, 1389-1397.

Sharp, P. M. \& Devine, K. M. (1989). Codon usage and gene expression level in Dictyostelium discoideum: highly expressed genes do 'prefer' optimal codons. Nucleic Acids Res 17, 5029-5039.

Sharp, P. M. \& Li, W.-H. (1987). The Codon Adaptation Index - a measure of directional synonymous codon usage bias, and its potential applications. Nucleic Acids Res 15, 1281-1295.

Sharp, P. M., Cowe, E., Higgins, D. G., Shields, D. C., Wolfe, K. H. \& Wright, F. (1988). Codon usage patterns in Escherichia coli, Bacillus subtilis, Saccharomyces cerevisiae, Schizosaccharomyces pombe, Drosopbila melanogaster and Homo sapiens: a review of the considerable withinspecies diversity. Nucleic Acids Res 16, 8207-8211.

Sharp, P. M., Higgins, D. G., Shields, D. C., Devine, K. M. \& Hoch, J. A. (1990). Bacillus subtilis gene sequences. In Genetics and Biotechnology of Bacilli, pp. 89-98. Edited by M. M. Zukowski, A. T. Ganesan \& J. A. Hoch. San Diego: Academic Press.

Sharp, P. M., Stenico, M., Peden, J. F. \& Lloyd, A. T. (1993). Codon 
usage: mutational bias, translational selection, or both? Biochem Soc Trans 21, 835-841.

Shields, D. C. (1990). Switches in species-specific codon preferences: the influence of mutation biases. J Mol Evol 31, 71-80.

Shields, D. C. \& Sharp, P. M. (1987). Synonymous codon usage in Bacillus subtilis reflects both translational selection and mutational biases. Nucleic Acids Res 15, 8023-8040.

Shinnick, T. M. (1987). The 65-kilodalton antigen of Mycobacterium tuberculosis. J Bacteriol 169, 1080-1088.

Stelandre, M., Bosseloir, Y., De Bruyn, J., Maes, P. \& Content, J. (1992). Cloning and sequence analysis of the gene encoding an NADP-dependent alcohol dehydrogenase in Mycobacterium bovis BCG. Gene 121, 79-86.

Takiff, H. E., Salazar, L., Guerrero, C., Philipp, W., Huang, W. M., Kreiswirth, B., Cole, S. T., Jacobs, W. R., Jr \& Telenti, A. (1994). Cloning and nucleotide sequence of Mycobacterium tuberculosis gyr $A$ and $g y r B$ genes and detection of quinolone resistance mutations. Antimicrob Agents Chemother 38, 773-780.

Thole, J. E. R., Keulen, W. J., Kolk, A. H. J., Groothuis, D. G., Berwald, L. G., Tiesjema, R. H. \& van Embden, J. D. A. (1987). Characterization, sequence determination, and immunogenicity of a 64-kilodalton protein of Mycobacterium bovis BCG expressed in Escherichia coli K-12. Infect Immun 55, 1466-1475.

Thomas, L. K., Dix, D. B. \& Thompson, R. C. (1988). Codon choice and gene expression: synonymous codons differ in their ability to direct aminoacylated-transfer RNA binding to ribosomes in vitro. Proc Natl Acad Sci US A 85, 4242-4246.

Thompson, J. D., Higgins, D. G. \& Gibson, T. J. (1994). Clustal w - improving the sensitivity of progressive multiple sequence alignment through sequence weighting, position-specific gap penalties and weight matrix choice. Nucleic Acids Res 22, 4673-4680.
Timm, J., Van Rompaey, I., Tricot, C., Massaer, M., Haeseleer, F., Fauconnier, A., Stalon, V., Bollen, A. \& Jacobs, P. (1992). Molecular cloning, characterization and purification of ornithine carbamoyltransferase from Mycobacterium bovis BCG. Mol \& Gen Genet 234, 475-480.

Wada, K.-n., Wada, Y., Ishibashi, F., Gojobori, T. \& Ikemura, T. (1992). Codon usage tabulated from the GenBank genetic sequence data. Nucleic Acids Res 20, 2111-2118.

Wright, F. (1990). The 'effective number of codons' used in a gene. Gene 87, 23-29.

Wright, F. \& Bibb, M. J. (1992). Codon usage in the $\mathrm{G}+\mathrm{C}$-rich Streptomyces genome. Gene 113, 55-65.

Yamaguchi, R., Matsuo, K., Yamazaki, A., Nagai, S., Terasaka, K. \& Yamada, T. (1988). Immunogenic protein MPB57 from Mycobacterium bovis BCG: molecular cloning, nucleotide sequence and expression. FEBS Lett 240, 115-117.

Yang, F., Lu, G. \& Rubin, H. (1994). Isolation of ribonucleotide reductase from Mycobacterium tuberculosis and cloning, expression, and purification of the large subunit. J Bacteriol 176, 6738-6743.

Young, D., Lathigra, R., Hendrix, R., Sweetser, D. \& Young, R. A. (1988). Stress proteins are immune targets in leprosy and tuberculosis. Proc Natl Acad Sci US A 85, 4267-4270.

Young, D. B., Kaufmann, S. H. E., Hermans, P. W. M. \& Thole, J. E. R. (1992). Mycobacterial protein antigens: a compilation. Mol Microbiol 6, 133-145.

Zhang, Y., Lathigra, R., Garbe, T., Catty, D. \& Young, D. (1991). Genetic analysis of superoxide dismutase, the 23 kilodalton antigen of Mycobacterium tuberculosis. Mol Microbiol 5, 381-391.

Received 10 August 1995; revised 6 December 1995; accepted 11 December 1995. 